\title{
PENGARUH SENAM ERGONOMIK TERHADAP TEKANAN DARAH LANSIA DENGAN HIPERTENSI
}

\author{
Suwanti*, Puji Purwaningsih, Umi Setyoningrum \\ Fakultas Keperawatan, Universitas Ngudi Waluyo, Jl. Diponegoro No.186, Mijen, Gedanganak, Kec. \\ Ungaran Timur, Semarang, Jawa Tengah, Indonesia 50512 \\ *wanticintanurfatwa@gmail.com (+6285779879951)
}

\begin{abstract}
ABSTRAK
Hipertensi merupakan penyebab kematian paling umum ketiga setelah stroke dan tuberkulosis. Penanganan yang tepat diperlukan untuk mencegah tidak terkontrolnya tekanan darah dan komplikasinya. Senam ergonomik sebagai terapi non farmakologi memiliki manfaat luas untuk mempertahankan kesehatan umum.Penelitian ini untuk menentukan pengaruh senam ergonomik terhadap terhadap tekanan darah lansia dengan hipertensi diWening Wardoyo Ungaran. Penelitian ini menggunakan pre experiment -one group pre-test post-test design. Sampel sebanyak 15 lansia dengan hipertensi yang diseleksi dengan purposive sampling. Pengambilan data dengan menggunakan lembar observasi dan Sphygmomanimeter air raksa (GEA Medical). Intervensi telah dilakukan sebanyak 3 kali per minggu. Test statistik menggunakan uji Wilcoxon. Hasil uji statistik dengan Wilcoxon menunjukkan $\mathrm{p}$ value sistolik $=0,000$ lebih kecil dari $\alpha$ value $(0,05), \mathrm{p}$ value diastolik $=0,011$ lebih kecil dari $\alpha$ value $(0,05)$. Hasil menunjukkan ada pengaruh yang signifikan senam ergonomik terhadap sistolik dan diastolik lansia. Peneliti menyarankan bahwa senam ergonomik dapat digunakan pada lansia dengan hipertensi sebagai terapi non farmakologi.
\end{abstract}

Kata kunci: lansia, senam ergonomik, hipertensi

\section{THE EFFECT OF ERGONOMIC EXERCISE ON BLOOD PRESSURE IN ELDERLY HYPERTENSION IN WENING WARDOYO UNGARAN}

\begin{abstract}
Hypertension is the third most common cause of death after stroke and tuberculosis. Proper handling is needed to prevent uncontrolled blood pressure and complications. Ergonomic exercise as non-pharmacological therapy has very broad benefits to maintain general health. This research aim to determine the effect of ergonomic exercise on blood pressure in elderly hypertention in Wening Wardoyo Ungaran. The research used pre experiment -one group pre-test post-test design. A sample of 15 elderly with hypertension was selected by purposive sampling. Data collecting used observation sheet and Sphygmomanometer (GEA medical). The intervention was done for 3 times/week. Statistical test used Wilcoxon.The result of test obtained $p$ value of sistolic $=0,000$ smaller than a value (0,05), $p$ value of diastolic $=0,011$ smaller than $\alpha$ value $(0,05)$. The results showed there were significant effect of ergonomic exercise on sistolic and sistolic. Researchers suggest that ergonomic exercise can be used in elderly hipertension as nonpharmacological therapy.
\end{abstract}

Keywords: elderly, ergonomic exercise, hypertension 


\section{PENDAHULUAN}

Hipertensi merupakan penyakit kronik dan masalah kesehatan yang sangat serius diberbagai negara maju maupun berkembang (Eugene \& Bourne, 2013). Hipertensi menjadi masalah kesehatan publik hampir diseluruh dunia dikarenakan penyakit hipertensi sebagai faktor resiko dari beberapa penyakit.Tingginya prevalensi hipertensi berkaitan dengan peningkatan komplikasi kardiovaskuler dan meningkatkan negative impact pada morbidity dan mortality rate didunia (WHO,2011). Lionakis (2013) menyatakan bahwa individu yang memasuki masa lansia akan mengalami perubahan pada sistem kardivaskuler berupa penurunan elastisitas di jaringan perifer yang menyebabkan terjadinya pelebaran pembuluh darah dan arterosklerosis. Hal inilah yang memicu terjadinya peningkatan prevalensi hipertensi pada lanjut usia (Zahrawardani, Herlambang, \& Anggraheny, 2013).

Peningkatan prevalensi hipertensi merupakan masalah serius didunia. Hipertensi telah membunuh 9.4 juta orang didunia. Hampir satu milliar penduduk didunia terkena hipertensi dan diprediksikan pada tahun 2025 meningkat sampai 1.56 milliar orang (29\%). American Heart Association (2011) melaporkan bahwa lebih 60\% lansia berusia lebih dari 65 tahun menderita hipertensi dan mengalami peningkatan lebih dari $70 \%$ pada usia 75 tahun. Penderita hipertensi lebih banyak terjadi dinegara berkembang (40\%). Asan \& Sambriong(2016) menyatakan bahwa usia sebagai salah satu faktor resiko terjadinya hipertensi, lansia beresiko terjadi hipertensi 11 kali lebih besar daripada kelompok usia sebelum lansia.
Mudahnya lansia terjadi hipertensi dikarenakan adanya proses degenerasi, adanya penurunan elastisitas pembuluh arteri dan kekakuan pembuluh darah (Rizkiyatiningsih, 2012; Thei, Sambriong, \& Gatum, 2008).

Di Indonesia, hipertensi menjadi penyebab ketiga kematian setelah stroke dan

tuberculosis (Depkes,RI,2007).Prevalensi hipertensi di Indonesia pada tahun 2004 sebesar $14 \%$, meningkat lebih dari $25.8 \%$ pada usia diatas 18 tahun tahun 2013 (Riskesdas RI,2013). Di Jawa Tengah, prevalensi Hipertensi dilaporkan lebih dari $26.4 \%$ tahun 2012) (Dinas Kesehatan Jawa Tengah, 2012). Pada tahun 2008 terdapat $42.9 \%$, kemudian mengalami peningkatan pada tahun 2009 sebanyak 4.9\%,dan meningkat menjadi $46.8 \%$. Prevalensi Hipertensi essensial di Kabupaten Semarang pada tahun 2011 sebesar 42.4\%. Di Unit Rehabilitasi sosial Wening Wardoyo Ungaran, penderita hipertensi 21 lansia(20\%).

Penatalakanaan saat ini dalam rangka menurunkan dan mencegah hipertensi mungkin belum secara efektif sehingga muncul hipertensi yang tak terkontrol (Profil Keshatan Semarang,2013). Pada kondisi seperti ini, hipertensi mengalami peningkatan yang sangat progresif dan menyebabkan komplikasi. Hipertensi disebut sebagai silent killer sehingga banyak penderita yang tidak mengetahui bahwa dirinya terkena hipertensi (Thei et al., 2008). Hipertensi dapat mempengaruhi kualitas hidup lansia (Febriyani,2016).

Penatalaksanaan farmakologis pada hipertensi pada lansia tentunya dapat mengakibatkan efek samping yang lebih serius sehingga terapi non farmakologis 
bisa menjadi pilihan karena memiliki resiko lebih rendah (Thei et al., 2008). Penanganan hipertensi dapat dilakukan mengubah pola hidup seperti mengurangi jumlah asupan garam, minuman beralkohol, menurunkan berat badan, rokok dan melakukan aktivitas fisik seperti olahraga (Lionakis, 2012). Salah satu terapi yang dapat diaplikasikan kepada lansia yaitu olahraga berupa senam ergonomik (Thei et al., 2008)

Manfaat dari senam ergonomik adalah mengontrol tekanan darah bermanfaat bagi kesehatan dan kebugaran.Senam Ergonomis merupakan senam yang gerakannya diadopsi dari gerakan shalat. Gerakan dalam senam ini sangat sederhana, bahkan minim gerakan, namun bila dilakukan secara konsisten dan kontinue, maka akan memberikan manfaat yang sangat baik bagi kesehatan. Manfaat gerakan senam ergonomis ini antara lain: Pengaktifan fungsi organ tubuh; membangkitkan biolistrik dalam tubuh dan melancarkan sirkulasi oksigen sehingga tubuh akan terasa segar dan energi bertambah; penyembuhan berbagai penyakit, mengontrol tekanan darah tinggi (Sagiran,2013; Nurfitri \&Asti,2016).Wratsongko (2016) dalam (Triwibowo, 2015) dan (Thei et al., 2008) menyatakan senam ini bermanfaat untuk mencegah dan menyembuhkan berbagai macam penyakit. Agar hasil yang didapatkan maksimal maka akan lebih baik jika senam ergonomik ini dilakukan secara berkelanjutan, sekurang kurangnya 2-3 kali seminggu dengan tiap sesi 20 menit dan apabila setiap gerakan tersebut dilakukan secara sempurna.

Modifikasi gaya hidup dan aktifitas fisik merupakan bagian yang sangat penting dalam managemen diri dalam upaya pengontrolan tekanan (Rigsby, 2011).
Berdasarkan penelitian bahwa senam ergonomik menyebabkan penurunan tekanan darah lansia (Febriyani,2016; Novita,2018; Thei et al., 2008; Nurfitri,2016). Penurunan tekanan darah akan lebih cepat dengan mengkombinasikan senam ergonomik dan yoga (Toton,2018).Senam ergonomik akan lebih efektif bila dilakukan berkelompok daripada individu (Priyanti, 2016). Senam ergonomik dapat membantu menurunkan tekanan darah penderita hipertensi dengan mengembalikan elastisitas pembuluh darah dan memperlancar peredaran darah (Nurfitri, 2016; Triwibowo,2015).

Meskipun tindakan pencegahan dan program kontrol untuk hipertensi telah dilakukan dalam berbagai kegiatan dan program, namun banyak orang yang tidak mampu memelihara tekanan darahya dalam batas normal. Berdasarkan wawancara terhadap staf di Unit Rehabilitasi Sosial Wening Wardoyo melaporkan bahwa penyakit yang paling banyak kedua adalah hipertensi. Meski banyak studi sebelumnya meneliti tentang senam ergonomik, namun diWening Wardoyo belum pernah dilakukan penelitian sebelumnya, selain itu tidak semua lansia muslim, sehingga tidak semua lansia terpapar dengan gerakan sholat, yang mana senam ergonomik mengadopsi dari gerakan sholat Senam yang dilakukan lansia hanya dilakukan bagi yang mampu berjalan.Selain itu ketiadaan tenaga keperawatan di unit URESOS yang mampu dalam managemen non farmakologis hipertensi. Pelaksanaan kegiatan senam tersebut diharapkan kualitas hidup lansia lebih baik. Apabila senam ergonomik dapat dilakukan pada lansia, diharapkan mampu membuat lansia merasa lebih percaya diri 
dan aman dari cidera.Lima gerakan yang sangat sederhana tersebut sangat memungkinkan para lansia mampu menerapkannya sehari-hari. Pemberian senam ergonomik yang benar dan kontinue yang disertai modifikasi gaya hidup yang lainnya diharapkan mampu mengontrol tekanan darah dalam batas normal. Oleh karena itu identifikasi pengaruh senam ergonomik dalam penurunan tekanan darah pada lansia di Unit Rehabilitasi Wening Wardoyo menjadi crucial untuk dilakukan dalam upaya untuk meningkatkan kualitas hidup lansia yang tinggal diwisma. Berdasarkan pada latar belakang dan kesenjangan situasi diWening Wardoyo Ungaran, maka peneliti tertarik untuk melakukan penelitian pre eksperimen "Adakah Pengaruh senam ergonomik Terhadap Tekanan Darah Pada Lansia dengan Hipertensi Di Unit Rehabilitasi Wening Wardoyo Ungaran".

\section{METODE}

Jenis penelitian ini merupakan penelitian pre experimental dengan one group pretest post-test design. Penelitian ini bertujuan untuk mengetahui ada tidaknya pengaruh pemberian intervensi berupa senam ergonomik terhadap tekanan darah penderita hipertensi pada lansia di Unit rehabilitasi Wening Wardoyo Ungaran. Penelitian telah dilakukan di Ruang Aula Unit Rehabilitasi Sosial Wening Wardoyo Ungaran dengan waktu penelitian selama satu minggu dari tanggal 03 Januari 201810 Januari 2018 dengan pelaksanaan senam 3 kali dalam satu minggu tersebut.

Populasi target dalam penelitian ini adalah semua lansia yang mengalami hipertensi yang tinggal di Unit Rehabilitasi Sosial Wening Wardoyo
Ungaran sebanyak 21 lansia. Teknik pengambilan sampel dengan non-random sampling dengan teknik perpusive sampling. Jumlah sampel dalam penelitian ini sebanyak 15 responden. Sampel yang dipilih adalah yang memenuhi kriteria inklusi yaitu Lansia yang tinggal di Unit Rehabilitasi Sosial Wening Wardoyo Ungaran, bersedia menjadi responden, menderita hipertensi , tidak ada keluhan pusing, lansia yang tidak ada mengkonsumsi obat hipertensi. Kriteria eksklusi: Lansia yang buta dan tuli, Menderita hipertensi berat dengan keluhan pusing, dan bedrest.

Sebelum dilakukan intervensi, peneliti dan asisten melakukan sosialisasi kepada calon responden dengan memperkenalkan diri, menjelaskan tujuan dan manfaat penelitian, dan menyeleksi calon responden berdasarkan kriteria inklusi dan eksklusi, ketersediaan partisipasi calon responden dengan penandatanganan informed consent. Pelaksanaan intervensi dan pengambilan data dilakukan di ruang aula Unit Rehabilitasi Sosial Wening Wardoyo yang sudah disetting sedemikian rupa agar keamanan (safety) klien terjaga yaitu menggunakan matras, dihindarkan dari benda-benda yang membahayakan, lapang, dan terjaga privacy responden.Alat pengumpul data dengan menggunakan lembar observasi dan Sphygmomanometer air raksa (Merk: GEA medical). Intervensi dilakukan tiga kali dalam seminggu dengan berselangseling harinya (alternate day).Pengambilan data tekanan darah dilakukan sebelum dilakukan intervensi senam ergonomik, setelah dilakukan tiga kali dalam seminggu, kemudian baru diukur tekanan darah (post test). Pengukuran tekanan darah menggunakan 
sphygmomanometer air raksa. Pada pelaksanaan penelitian ini peneliti memperhatikan etika penelitian yaitu informed consent, anonimity, confidentiality, non malficence dan beneficency.

Analisa data meliputi analisis univariat dan analisis bivariat. Uji normalitas data dengan menggunakan Saphiro Wilk, dan data terdistribusi tidak normal. Analisis bivariat untuk mengetahui pengaruh pemberian senam ergonomik terhadap tekanan darah pada lansia dengan hipertensi maka dilakukan uji statistik dengan menggunakan uji Wilcoxon.

\section{HASIL}

Jumlah responden lansia di Unit Rehabilitasi Sosial Wening Wardoyo Ungaran pada bulan Oktober 2017 sebanyak 98 lansia/penerima manfaat, sedangkan yang menderita Hipertensi sebanyak 21 lansia. Dari semua calon responden lansia penderita hipertensi dan lansia yang memenuhi kriteria inklusi sebanyak 15 responden lansia. Setelah dilakukan intervensi senam ergonomik terhadap lansia yang tinggal di Unit Rehabilitasi Wening Wardoyo Ungaran pada tanggal 03 Januari 2018-10 Januari 2018 didapatkan hasil penelitian yang akan disajikan hasil penelitian yang akan disajikan pada tabel sebagai berikut:

Tabel 1.

Karakteristik lansia dengan hipertensi berdasarkan umur dan jenis kelamin $(n=15)$

\begin{tabular}{llcc}
\hline \multicolumn{1}{c}{ Karakteristik responden } & & $\mathrm{f}$ & $\%$ \\
\hline Umur & 60-70 tahun & 8 & 53 \\
& $71-80$ tahun & 4 & 26 \\
& $>80$ tahun & 3 & 20 \\
\hline Jenis Kelamin & Perempuan & 11 & 73 \\
& Laki-laki & 4 & 27 \\
\hline
\end{tabular}

Tabel 1 menunjukkan bahwa sebagian adalah perempuan sebanyak 11 orang besar responden lansia berusia 60-70 (73\%).

tahun dan sebagian besar responden

Tabel 2.

Rata-rata tekanan darah sebelum dan sesudah diberikan senam ergonomik pada lansia dengan hipertensi $(n=15)$

\begin{tabular}{lcc}
\hline & Mean & SD \\
\hline Sistolik pre test & 151,33 & 12,743 \\
Sistolik post test & 142,00 & 12,364 \\
\hline Diastolik pre test & 90,66 & 2,58 \\
Diastolik post test & 86,33 & 4,80 \\
\hline Tabel 2 menunjukkan adanya penurunan & penurunan rata-rata diastole & setelah \\
rata-rata sistole setelah diberikan senam & diberikan senam ergonomik sebesar 4,33 \\
ergonomik sebesar 9,33 mmHg, adanya & mmHg.
\end{tabular}


Tabel 3.

Pengaruh senam ergonomik terhadap tekanan darah lansia dengan hipertensi $(n=15)$

\begin{tabular}{llccc}
\hline Tekanan Darah pre-test post-test & Median & Min & Max & Nilai p \\
\hline Sistolik sebelum Ergonomic Exercise & 150 & 140 & 190 & 0,000 \\
Sistolik sesudah Ergonomic Exercise & 135 & 130 & 180 & \\
\hline Diastolik sebelum Ergonomic Exercises & 90 & 90 & 100 & 0,011 \\
Diastolik sesudah Ergonomic Exercises & 90 & 80 & 90 & \\
\hline Tabel 3 menunjukkan hasil test statistik & hipertensi menduduki urutan kedua \\
dengan uji Wilcoxon. Hasil menunjukkan & sebesar 15,2\% setelah artritis/reumatisme, \\
nilai sistolik (p value=0,000), dan untuk & berdasarkan Disease Pattern of people \\
nilai diastolik (p value =0,011, karena & $>55$ years (Household Survey on Health, \\
nilai p value $<0,05$, maka dapat & Department of Health, 1996) \\
disimpulkan bahwa secara statistik & menunjukkan penyakit kardiovaskuler \\
terdapat pengaruh yang signifikan senam & yang terbanyak 15,7\% dan menjadi \\
ergonomik terhadap tekanan darah lansia & keluhan banyak lansia (Azizah, 2013)
\end{tabular}

dengan hipertensi di Unit Rehabilitasi Wening Wardoyo Ungaran.

\section{PEMBAHASAN}

Tabel 1 menunjukkan angka kejadian penyakit hipertensi pada lansia sebanyak 8 responden $(53 \%)$ terjadi pada usia lansia 60-70 tahun, dan 7 responden berusia diatas 70 tahun. Angka kejadian hipertensi banyak terjadi pada lansia. Hal ini selaras dengan pendapat Lubkin \& Larsen (2013) yang menyatakan bahwa yang terbesar penyakit kronis terjadi pada usia 65 tahun dan lebih. Hal yang mirip dengan temuan (WHO,2013) yang menyatakan sekitar $40 \%$ orang dewasa berusia 25 tahun atau lebih di dunia telah didiagnosis dengan hipertensi, jumlah orang dengan kondisi hipertensi naik dari 600 juta pada tahun 1980 menjadi 1 miliar pada tahun 2008 yang paling banyak terjadi pada usia lanjut. Penyakit yang terbanyak pada lanjut usia adalah hipertensi (Azizah, 2013). Penyakit yang sering terjadi pada lansia pada gangguan sirkulasi darah salah satunya adalah hipertensi. Hal tersebut juga diperkuat oleh temuan WHO-Community Study of the Elderly of Central Java penyakit

Hal ini dikarenakan dengan bertambahnya usia, individu akan mengalami penurunan fungsi kardiovaskuler meliputi penebalan katub jantung dan menjadi kaku, dan kemampuan jantung memompa darah menurun. Hal ini menyebabkan menurunnya kontraksi jantung dan volumenya. Pembuluh darah juga kehilangan elastisitas pembuluh darah, dan tekanan darah meningkat akibat meningkatnya resistensi pembuluh darah perifer. Pada lansia umumnya mengalami penurunan besarnya sel-sel otot jantung, hal ini menyebabkan menurunnya kekuatan otot jantung dalam memompa darah, masalah ini semakin memburuk karena adanya penurunan besar jantung dan penurunan rongga bilik kiri (Azizah, 2011). Pada lansia umumnya mengalami penurunan besarnya sel-sel otot jantung, hal ini menyebabkan menurunnya kekuatan otot jantung dalam memompa darah, masalah ini semakin memburuk karena adanya penurunan besar jantung dan penurunan rongga bilik kiri. Hal ini diperkuat oleh pendapat Asan \& Sambriong(2016) yang menjelaskam 
bahwa usia merupakan salah satu faktor terjadinya hipertensi, dan jika usia lebih dari 60 tahun keatas beresiko 11 kali lebih besar dari usia dibawah 60 tahun. Hal ini selaras dengan semua usia responden dalam penelitian ini, dimana semua responden diatas 60 tahun, bahkan separo dari responden berusia diatas 70 tahun.

Sedangkan hasil penelitian ini kejadian hipertensi pada kelompok umur 71-80 tahun lebih sedikit prosentasenya yaitu sebanyak 4 lansia (26\%) dan yang >80 tahun sebanyak 3 lansia(20\%). Hal ini sesuai dengan hasil wawancara dengan staf di Unit rehabilitasi, bahwa banyak lansia yang sudah meninggal dunia dikarenakan penyakit hipertensinya yang sudah terjadi komplikasi. Seiring bertambahnya usia perubahan yang sangat bermakna yaitu adanya pengapuran pada dinding pembuluh darah yang bisa terjadi dimana-mana, dan jika proses ini berlanjut akan menyebabkan hambatan aliran darah dan bahkan menutup pembuluh tersebut. Bila hal ini berlanjut dan sumbatan tersebut teraliri zat asam, pembuluh tersebut akan rusak/mati (infark), dan bila terjadi diotak akan menjadi stroke dan bila terjadi dijantung akan terjadi infark miokard. Di Indonesia penyakit komplikasi dari hipertensi yaitu penyakit jantung iskemia menjadi pembunuh ketiga diantara penyakit-penyakit lainnya. Penyakit tersebut diantaranya terjadi pada lansia.

Hasil penelitian pada tabel 1, responden lansia yang paling banyak menderita hipertensi adalah perempuan, yaitu sebanyak 11 orang $(73 \%)$. Hal ini sesuai dengan hasil penelitian sebelumnya yang menyatakan kejadian hipertensi lebih banyak terjadi pada perempuan. (Kusumawaty et al., 2016 \& Shep ,
2005). Perempuan lebih tinggi kejadian hipertensinya dikarenakan lansia sudah mengalami menopause. Kondisi menopouse mengalami penurunan hormon estrogen, sehingga terjadi penurunan High Density Lipoprotein (HDL), sehingga meningkatkan kejadian aterosklerosis, sehingga wanita rentan terhadap hipertensi (Anggraeni , 2011). Hal ini juga didukung oleh pernyataan Darmojo (2004) dalam (Azizah,2011) dan WHO-Community Study of the elderly of Central Java 1990, bahwa kejadian hipertensi pada wanita lebih tinggi daripada pada pria. Menurut Lehler, Rabin, Kalir, dan Schachter (1993) dalam (Adhita \& Pramuningtyas, 2010) menyatakan bahwa prevalensi hipertensi pada pria dan wanita berbeda dan tergantung umur. Pada individu dengan umur 25 - 54 tahun, hipertensi lebih sering terjadi pada pria sedangkan individu dengan umur lebih dari 54 tahun, hipertensi lebih sering terjadi pada wanita.

Kusumawaty menyatakan et al (2016) bahwa dengan bertambahnya umur, maka tekanan darah juga akan meningkat Menurut Yusnidar (2007), batasan umur $\geq$ 45 merupakan batas usia perimenopause/ menopause pada wanita. Dikatakan bahwa wanita yang sudah tidak haid lebih berisiko terhadap penyakit kardiovaskuler karena tingkat estrogennya menurun. Hal ini kontradiktif dengan hasil penelitian (Adhita \& Pramuningtyas, 2010) yang melakukan penelitian pada 76 perempuan dan 76 laki-laki penderita DM yang menjalani perawatan jalan di RSUD Moewardi Surakarta, menyatakan bahwa tidak ada perbedaan yang bermakna kejadian hipertensi pada wanita penderita Diabetes Mellitus (38,16\%) dibandingkan pada pria penderita 
Diabetes Mellitus (35,53\%). Hasil penelitian tersebut selaras dengan hasil penelitian (Cortas , 2013) yang mengatakan prevalensi terjadinya hipertensi pada pria sama dengan pada wanita. Hasil penelitian ini juga kontras dengan hasil penelitian sebelumnya, yaitu hasil penelitian (Yunus,2005) yang meneliti Prevalence of Cardiovascular Risk Factors in a Rural community in Mukim Dengkil, Selangor menyatakan bahwa pada pria mempunyai prevalensi yang lebih tinggi $(31,7 \%)$ secara bermakna dibandingkan dengan wanita $(23,5 \%)$. Hasil penelitian yang kontra juga diketemukan pada hasil penelitian oleh (Mufunda et al,2006), The Prevalence of Hypertension and Its Relationship with Obesity: Results from a National Blood Pressure Survey in Eritra, dari keseluruhan, prevalensi hipertensi pada pria $(16,88 \%)$ didapatkan hanya sedikit lebih tinggi dari wanita $(15,28 \%)$. Sedangkan penelitian yang dilakukan oleh ( National Academy on Aging Society,2005), Hypertension A common condition for older Americans in Challenges for the 21st Century: Chronic and Disabling Condition, mengemukakan bahwa pria dan wanita rata- rata nyaris mempunyai angka kejadian hipertensi yang sama sebelum usia 65 tahun, selisih itu akan bertambah lebar ditahun-tahun berikutnya.

Tabel 2 menunjukkan rata-rata (mean) tekanan darah sistolik dan diastolik sebelum dan sesudah diberikan intervensi senam ergonomik. Rata-rata tekanan sistolik pre-test sebesar $151,33 \mathrm{mmHg}$ dan tekanan darah sistolik setelah diberikan intervensi senam ergonomik menjadi rata-rata $142,00 \mathrm{mmHg}$. Sedangkan rata-rata tekanan diastolik pretest sebesar 90,66 mmHg dan tekanan diastolik setelah diberikan senam ergonomik mengalami penurunan ratarata menjadi $86,33 \mathrm{mmHg}$. Dari 15 respopnden lansia, terdapat semua lansia (15 responden) mengalami penurunan sistolik sebesar rata-rata $9,33 \mathrm{mmHg}$ setelah diberikan senam ergonomik. Sedangkan untuk tekanan diastolik semua responden juga mengalami penurunan diastolik rata-rata $8 \mathrm{mmHg}$. Tekanan darah sistolik pre-test tampak rata-rata masih tinggi, dan setelah intervensi $3 x$ tampak mengalami penurunan, begitu juga untuk diastoliknya.

Tabel 3 menunjukkan hasil test statistik dengan uji Wilcoxon untuk nilai sistolik ( $\mathrm{p}$ value $=0,000$ ), dan untuk nilai diastolik ( $\mathrm{p}$ value $=0,011)$, karena nilai $\mathrm{p}$ value $<0,05$. Disimpulkan bahwa secara statistik terdapat pengaruh yang signifikan senam ergonomik terhadap tekanan darah lansia dengan hipertensi di Unit Rehabilitasi Wening Wardoyo Ungaran. Berdasarkan hasil tersebut diketahui bahwa setelah diberikan senam ergonomik semua lansia mengalami penurunan tekanan sistolik dan diastolik. Asumsi dari peneliti penurunan tekanan darah tersebut dikarenakan intervensi senam ergonomik. Gerakan-gerakan senam ergonomik yang dilakukan oleh responden merupakan gerakan-gerakan senam ergonomis, yang mana gerakan sederhana ini sesuai dengan kaidahkaidah penciptaan tubuh manusia, gerakan ini mampu secara langsung membuka, membersihkan, dan mengaktifkan seluruh sistem-sistem tubuh seperti sistem kardiovaskuler, kandung kemih (Wratsongko,2015). Dengan gerakan-gerakan ergonomik ini, akan teroptimalkan posisi tubuh lansia, terminimalkan kelelahan dan meningkatkan kenyamanan lansia. 
Dengan melakukan gerakan ergonomik, akan mengembalikan atau membetulkan posisi dan kelenturan sistem saraf dan aliran darah, sehingga memaksimalkan suplai oksigen ke otak, dan sistem kesegaran tubuh. Berdasarkan pada pelaksanaan senam ergonomik, mayoritas lansia mampu melakukan semua gerakan dengan baik, hal ini tentunya akan berpengaruh terhadap tekanan sistolik diastolik lansia. Meskipun ada 3 lansia yang mengalami penurunan sistolik dan diastolik hanya $5 \mathrm{mmHg}$, kemungkinan 3 lansia yang tidak optimal dalam melakukan gerakan terakhir (gerakan berbaring pasrah) dengan alasan kaki susah ditekuk, sehingga gerakan tersebut tidak maksimal menurunkan sistolik dan atau diastolik.

Posisi berdiri sempurna (gerakan pembuka), dengan gerakan ini membuat punggung kebanyakan lansia mampu lurus secara maksimal, sehingga posisi ini mampu memperbaiki bentuk tubuh lansia dan menormalkan kerja jantung, dan saat fikiran dipadukan dengan tujuan sehat tanpa beban, hal ini akan mengoptimalkan manfaatnya. Posisi lapang dada, mayoritas lansia mampu melakukan gerakan kedua ini. Posisi ini membuat seluruh saraf menjadi satu titik pusat pada otak. Pusat otak bagian atas dan bawah dipadukan membentuk satu tujuan, dan saat itu pikiran akan dikendalikan oleh akal budi, sehingga tubuh merasa dibebaskan dari beban, karena pembagian beban yang sama pada kedua kaki. Pada waktu berdiri seperti ini dengan kedua kaki posisi tegak, akan menekan seluruh titik saraf ditelapak kaki hal ini bermanfaat bagi kesehatan, salah satunya akan memperbaiki kerja jantung bekerja secara normal (Wratsongko,2015). Hal ini selaras dengan hasil penelitian Febriyani (2016); Novita (2018); Nurfitri (2016); Thei et al., (2008); Triwibowo ( 2015).

Posisi tunduk syukur (gerakan ruku'), mayoritas lansia mampu melakukannya dengan baik, dan satu lansia yang tidak mampu melaksanakan secara maksimal. Hampir semua lansia yang mengatakan merasa rileks atau nyaman pada posisi ini. Hal ini sesuai dengan pendapat Thei et al (2008); Triwibowo ( 2015) \& Wratsongko (2015) dengan membungkukkan badan kedepan dan tangan memegangi pergelangan kaki, hal ini akan menyebabkan posisi tulang belakang sebagai tempat juluran saraf tulang belakang berada relatif dalam posisi segmental anatomis-fungsional (segmen dada-punggung) yang lurus menyebabkan relaksasi dan memaksimalkan fungsi serabut saraf segmen tersebut. Kondisi rileks memungkinkan oksigen dapat mengalir lancar keseluruh tubuh, kondisi rileks juga menyebabkan pembuluh darah mengalami vasodilatasi dan meminimalkan tahanan. Kondisi relaks ini sangat membantu lansia dalam penurunan tekanan darahnya.Posisi duduk perkasa, pada posisi ini mayoritas lansia masih mampu melakukannya dengan baik, posisi ini akan memaksimalkan tekukan ruas jari kaki akan memaksimalkan pengaktifan tomboltombol saraf dan membuang energi negatif dari dalam tubuh. Dengan pengeluaran energi negatif ini akan menstabilkan bio-listrik dalam tubuh. Jika semakin meningkat kekacauan bio-listrik lama kelamaan akan mengganggu fungsi otak yang mengendalikan semua aktifitas tubuh kita. jika semakin meningkat kekacauan bio-listrik lama kelamaan akan mengganggu fungsi otak yang 
mengendalikan semua aktifitas tubuh kita (Wratsongko, 2015).

Posisi duduk pembakaran, semua lansia mampu melakukan gerakan ini dengan baik, dan ada satu lansia yang tidak mampu melakukannya karena dengan menekuk kaki akan terasa sakit. Posisi ini akan menyebabkan polarisasi medan magnet ditelapak kaki dan menjadi konversi energi negatif menjadikannya energi pembakaran, salah satunya membakar kolesterol. Pada posisi ini, pembuluh balik yang berada dipangkal lutut dikunci, sehingga tekanan darah digunakan untuk mengisi pembuluh darah halus yang ada dipangkal kaki. Pembuluh nadi tetap terbuka sehingga aliran darah tidak terhenti (Rizkiyatiningsih, 2012; Triwibowo,2015 \& Wratsongko, 2015). Hal inilah yang akan membuat badan lansia terasa lebih ringan, rileks dan segar dan tekanan darah menurun. Posisi berbaring pasrah, gerakan ini adalah gerakan yang paling sukar dilakukan, dan ada 3 lansia yang kesusahan dalam posisi ini. Bagi lansia yang mampu melakukannya, posisi ini membuat lenturnya tulang belakang, akan menyebabkan seluruh saraf akan bekerja secara optimal terutama aliran bio-listrik, relaksasi optimal, dikarenakan posisi ini, struktur tulang belakang mendekati meluruh, dimana lekukan anatomis segmental tulang belakang yang diikuti saraf tulang belakang menyebabkan tarikan pada serabut saraf berkurang, sehingga lansia berkesempatan merasakan perasaan relaks sehingga membantu menurunkan tekanan darah lansia. Secara keseluruhan latihan relaksasi pada senam ergonomik yang dikombinasikan dengan pernafasan yang terkontrol dan rangkaian kontraksi serta relaksasi otot hal ini menghasilkan respon relaksasi fisik dan psikologis lansia secara maksimal,mudah istirahat,peningkatan sekresi serotonin yang menyebabkan penurunan.

\section{SIMPULAN}

Ada pengaruh yang signifikan senam ergonomik terhadap tekanan darah sistolik sebelum dan sesudah senam ergonomik ( $p$ value $=0,000)$ dan ada pengaruh yang signifikan pada tekanan darah diastolik sebelum dan sesudah senam ergonomik ( $p$ value $=0,011)$ pada lansia dengan hipertensi di Unit Rehabilitasi Wening Wardoyo Ungaran.

\section{UCAPAN TERIMAKASIH}

Terima kasih yang sebesar-besarnya kepada Universitas Ngudi Waluyo yang telah mensupport pendanaan dalam penelitian ini (Hibah internal) dan khususnya kepada pihak Lembaga Penelitian dan Pengabdian Masyarakat Universitas Ngudi Waluyo yang telah memfasilitasi dalam pelaksanaan penelitian ini.

\section{DAFTAR PUSTAKA}

Adhita, P. M., \& Pramuningtyas, R. (2010). Perbedaan angka kejadian hipertensi antara pria dan wanita penderita diabetes mellitus berusia z45 Tahun. Biomedika,2(2), 67-71.

American Heart Association.(2011). Hypertension in older people. Availabe Source: http://content.onlinejacc.org/cgi/con tent/full/j.jacc.2011.01.008, Retrieved Januari 1, 2018

Anggraini (2012). Jenis kelamin pada penderita hipertensi. Bandung: PT Remaja Rosida Rosida Karya 
Asan Y., Sambriong M., \& Gantung. A. M. (2016). Perbedaan tekanan darah sebelum dan sesudah terapi rendam kaki air hangat pada lansia di UPT panti sosial penyantunan lanjut usia budi agung kupang. CHMK jurnal, $11(2)$, 37-42. $\quad$ http://cyberchmk.net/ojs/index.php/kesehatan/a rticle/view/30/26 diakses 14 November 2019

Azizah, L.M (2011). Keperawatan Lanjut Usia. Yogyakarta : Graha Ilmu

Dinas Kesehatan Jawa Tengah.(2012).Profil kesehatan provinsi Jawa Tengah tahun 2012.Dinas kesehatan Jawa Tengah http://dinkesjateng.go.id/download/ pdf.akses Januari 20, 2017

Depkes .(2013).Riset Kesehatan Dasar 2013.

http://depkes.go.id/download/riskes das 2013/Hasil\%202013.pdf. Januari 18,2017

Eugene, V., \& Bourne, P. (2013). Hypertensive patients: knowledge, self-care management practices and challenges. Journal of Behavioral Health, 2(3), 259. https://doi.org/10.5455/jbh.2013021 7103511

Febriyani,I. (2016).Pengaruh senam ergonomik terhadap tekanan darah pada lansia hipertensi di Bulus Wetan Sumber Agung wilayah kerja puskesmas Jetis Batul. Junal of Nursing, http://repository.unjaya.ac.id/eprint/ $610,18 / 8 / 2019$

Kusumawaty, J., Hidayat, N., \& Ginanjar,
E. (2016). Hubungan Jenis Kelamin dengan Intensitas Hipertensi pada Lansia di Wilayah Kerja Puskesmas Lakbok Kabupaten Ciamis. Mutiara Medika, 16(2), 46-51.

Lionakis, Nikolaos; Mendrinos, Dimitros; Sanidaas, Elias; Favatas, Georgios \& Georgo Poulou. (2012).

Hypertension In The Elderly. World Journal Of Cardioly Volume 4 (5): 135-147. doi :

10.4330/wjc.v4.i5.135

Lubkin, I.M. and Larsen, P.D. (2013) Chronic Illness: Impact and Intervention.Burlington:Jones and Bartlett Publishers

Novita,W.E\&Wisudariani,E.(2018).Penga ruh senam ergonomis terhadap pengendalian dan pencegahan penyakit hipertensi di wilayah kerja puskesmas Rawasari kota Jambi. vol.34,No.11, https://jurnal.ugm.ac.id/bkm/article/ view/39059, akses 13/11/2019

Nurfitri,R, Budiharto,I,\&Yulanda,N.A.(2016)/ Pengaruh senam ergonomik terhadap perubahan tekanan darah lansia dengan hipertensi. Jurnal keperawatan

Mufunda, Mebrahtu,G.et al.(2006). The prevalence of hypertension and its relationship with obesity: result from a national blood pressure survey in Eritrea,20(1):59-65

Priyanti, Kikin. (2016). Pengaruh Senam Ergonomik Secara Kelompok Dan Individu Terhadap Penurunan Tekanan Darah Pada Lansia 
Dengan Hipertensi Di Kelurahan Gisikdrono Semarang. Jurnal Ilmu Keperawatan Dan Kebidanan. Volume 1, No 2: 1-15

Sheps, S. G. (2005). Mayo clinic hipertensi:Mengatasi tekanan darah tinggi.Jakarta:Intisari Mediatama,https://www.worldcat.or g/litle/mayo-clinic-hipertensimengatasi-tekanan-darahtinggi/oclc/298399278, novemver 2019

Rigsby, B. (2011). Hypertension improvement through healthy lifestyle modifications. The $A B N F$ Journal: Official Journal of the Association of Black Nursing Faculty in Higher Education, Inc, $22,41-43$.

Rizkiyatiningsih.(2012).Pengaruh senam ergonomik terhadap penurunan tekanan darah pada hipertensi derajat I pada lansia didesa wironanggan kecamatan gatak sukoharjo,jurnal keperawatan unimus

Sagiran. (2013). Mukjizat sholat. Yogyakarta:Nuha Medika press

Scott, A. K. (2013). Hypertension in the elderly Hypertension in the elderly. 4(April 2001), 199-207. https://doi.org/10.4330/wjc.v4.i5.13 5
Thei, A. D. ., Sambriong, M., \& Gatum, A. (2008). Pengaruh senam ergonomik terhadap penurunan tekanan darah pada lansia yang mengalami hipertensi di UPT Panti sosial penyantun budi agung kota Kupang.vol 1 No.1, 18-22. http://cyberchmk.net/ojs/index.php/sains/article /view/341,13 november 2019

Toton,P.T, Perwiraningtyas,P.\&Ardiyani,V.M. (2018).Perbedaan senam ergonomik dan yoga terhadap perubahan tekana darah pada lansia dengan hipertensi dipanti jompo griya kasih siloam

malang,Nursingnewsjurnal:ilmukep erawatan,Vol.3,No.3(2018),http://p ublikasi.unitri.ac.id/index.php/fikes/ article/view/1315

Wratsongko,M.(2015).Mukjizat Gerakan Sholat dan Rahasia 13 Unsur:Yogyakarta:Nuha Medika

Zahrawardani, D., Herlambang, K. S., \& Anggraheny, H. D. (2013). Analisis faktor risiko kejadian penyakit jantung koroner di RSUP Dr Kariadi Semar Jurnal Kedokteran Muhammadiyah, 1(3), 13. Retrieved from http://jurnal.unimus.ac.id/index.php /kedokteran/article/view/1341 